mativa multipla tipo Goldenhar in soggeto con delezione del braccio corto del cromosoma 18. Minerva Pediatrica, 28, 716-729.

de Grouchy, J. (1969). The $18 \mathrm{p}-, 18 \mathrm{q}-$ and $18 \mathrm{r}$ syndromes. Birth Defects: Original Article Series, 5, No 5, 74-87. The National Foundation-March of Dimes, New York.

de Grouchy, J., Lamy, M., Thieffry, S., Arthuis, M., and Salmon, C. (1963). Dysmorphie complexe avec oligophrénie: délétion des bras courts d'un chromosome 17-18. Comptes Rendus Hebdomadaires des Séances de l'Académie des Sciences, 256, 1028-1029.

Faust, J., Habedank, M., and Nieuwenhuijsen, C. (1976). The 18p- syndrome. European Journal of Pediatrics, 123, 59-66.

Funderburk, S. J., Sparkes, R. S., and Klisak, I. (1977). 18psyndrome resulting from $14 \mathrm{q} / 18 \mathrm{q}$ 'dicentric' fusion translocation. Human Genetics, 39, 243-250.

Lurie, I. W., and Luzjak, G. I. (1972). Partial monosomies 18. Humangenetik, 15, 203-222.

Seabright, M. (1971). A rapid banding technique for human chromosomes. Lancet, 2, 971-972.

Sumner, A. T. (1972). A simple technique for demonstrating centromeric heterochromatin. Experimental Cell Research, 75, 304-306.

Requests for reprints to $\mathrm{Dr}$ S. J. Funderburk, Neuropsychiatric Institute, 760 Westwood Plaza, Los Angeles, California 90024, USA.

\section{Brachydactyly and polydactyly with dermal ridge dissociation and ridge hypoplasia}

SUMMARY A child with brachymesophalangy and postaxial postminimal polydactyly was found also to have dermal ridge dissociation and ridge hypoplasia. She was the second child of unaffected, unrelated parents and was born after a normal pregnancy and delivery. No previous report of a similar combination has been traced.

Brachydactyly may either occur as an isolated developmental defect, usually inherited in an autosomal dominant manner, or as part of a more complex malformation not confined to the extremities. The classification of isolated brachydactyly is based on that of Bell (1951), who recognised three types with brachymesophalangy (shortening of middle phalanges) alone, types $\mathrm{A} 1, \mathrm{~A} 2$, and $\mathrm{A} 3$; three further forms of brachyphalangy, types B, C, and D (stub thumbs); and a form with brachymetacarpy and brachymetatarsy, type E. In 1970, Edwards and Gale described a mixed type combining brachymesophalangy, brachymetacarpy, brachymetatarsy, and camptodactyly. More recently, Christian et al. (1972) reported a new form of preaxial brachy- dactyly with short thumbs and first toes angulated a the metacarpophalangeal or metatarsophalangeat. joint. Bilginturan et al. (1973) described a new fornef of combined brachyphalangy, brachymetacarpy, an brachymetatarsy associated with hypertension. Othe developmental disorders associated with brachy dactyly that have been reported include join 1 dysplasia (Liebenberg, 1973), and cerebellar ataxi\% with nystagmus (Biemond,. 1934). Since Bell's. account, two new types of brachymesophalangy have been described, that of Temtamy (1966), type A4 $\frac{\overrightarrow{\mathrm{e}}}{2}$ and that of Bass (1968), type A5. Schott (1978) has also recently published an account of a family with $\overline{\bar{B}}$ new form of type B brachydactyly (shortening of terminal and, to a lesser extent, middle phalanges) and Sillence (1978) has indicated further hetero geneity in type A1 brachydactyly. In Schott's family hands, but not feet, were involved, the thumbs were spared, and there was an associated nail dysplasia of the affected fingers. The findings on the hands and feet of the five members of a kindred seen by Sillence were consistent with type A1 brachydactyly, buo they also had tall normal stature, scoliosis, and club feet. None of these different types of brachydactyly involved polydactyly, dermal ridge dissociation, an ridge hypoplasia as was seen in the sporadic case reported here.

\section{Case report}

The patient was a girl born on 18.7.71. She was born at term after a normal pregnancy and delivery, wits a birthweight of $3.97 \mathrm{~kg}$. Her mother was 27 years old and her father 32 years at the time of her birth A normal elder sister was born in June 1970. The patient was noted at birth to have bilateral smaE fleshy fingers with nails, attached by a narrow piece of skin to the proximal phalangeal region of the outes border of the fifth fingers. There was a similar posto axial toe on the right foot but not on the left. A three extra digits were removed shortly after birth.

She was seen, with her parents and sister, in $197 \%$ for an opinion relating to her possible acceptance for immigration abroad. At that time, direcf. examination of her parents and sister showed n\& abnormality of hands or fingers and no history could be obtained of such abnormality in any furthe member of the family. There was no parentaq consanguinity (Fig. 1).

On examination, the patient showed small scaf where her extra digits had been removed. The secon $\frac{\text { S }}{\text { S }}$ to fifth fingers of both hands were slightly short, but her thumbs were of normal length (Fig. 2). Thero was some limitation of flexion of the distal joint of the right thumb. There was no further abnormalit? of the limbs other than in the digits and she has 
normal nails, hair, and teeth. Her height was $889 \mathrm{~cm}$, which is between the 25th and 50th centiles for her age. No evidence of any cardiac defect could be elicited.

I

II

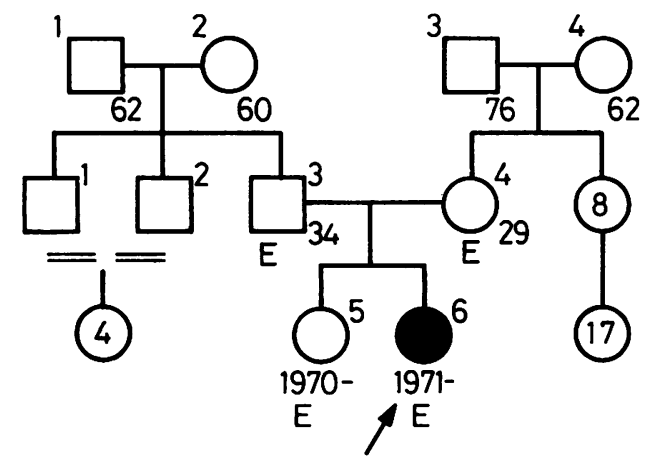

$E=$ Examined by authors

Fig. 1 Pedigree of family.

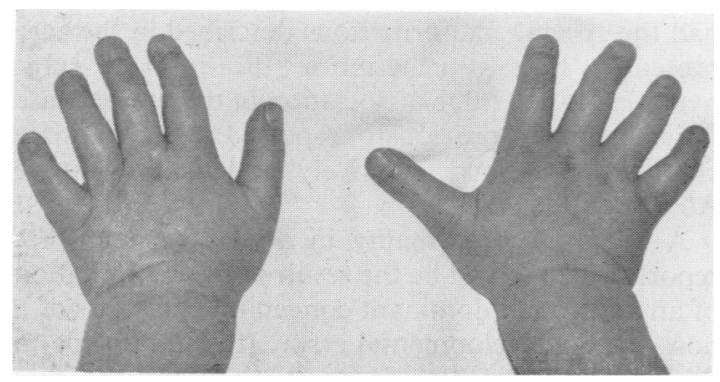

Fig. 2 Photograph of hands of the patient.

\section{DERMATOGLYPHS}

There was a marked ridge hypoplasia on the fingers and over the thenar eminence and distal part of the palms. This peculiarity was also observed on the toes and distal part of the soles, including the thenar distal and hypothenar distal regions of the sole.

Ridge dissociation of the 'dotted' type also occurred on her fingertips. The dotted ridges were clearly defined at the margins of the fingertips (Fig. 3 ), but there was a gradual change of the dotted ridges from mild to more severe dissociation from the distal towards the proximal regions of the fingertips.

Fingerprint patterns and dental wax impressions of her fingertips showed ulnar loops on all ten remaining fingers. On both palms there was a digital triradius, proximal to the site from which the extra postaxial finger had been removed, and bilateral patterns on interdigital areas I and III; the former were associated with an $e$ triradius (Fig. 4). Foot prints of the proband were not taken nor were her sole patterns recorded.

Her parents and sister had normally formed ridges.

\section{RADIOGRAPHIC FINDINGS}

$X$-rays of the hands (Fig. 5) showed that all the fingers had only two phalanges, a proximal and a terminal phalanx. In addition, there was a small round bone in place of the middle phalanx of the middle right finger and the index and middle left fingers. These bones could be regarded as severely reduced middle phalanges and they were associated with ulnar deviation of their terminal phalanges.

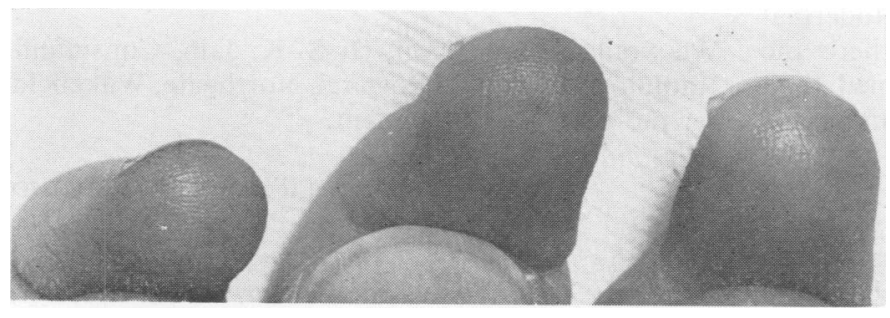

Fig. 3 Photograph of patient's finger tips to show ridge pattern.
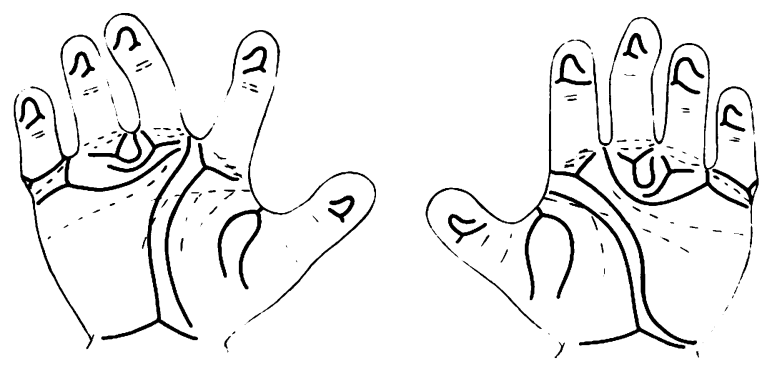

Fig. 4 Dermatoglyphic analysis of patient's hands. 


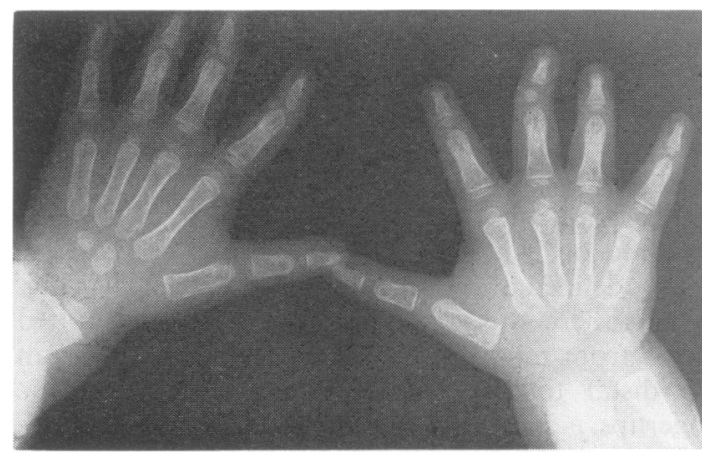

Fig. $5 \quad X$-ray of patient's hands.

Separate capitate and hamate bones could be seen in each carpus. $X$-rays of the feet showed missing middle phalanges in the second, fourth, and fifth toes on both sides, with severely reduced middle phalanges in the third toes similar to those in the middle fingers. There was no abnormality in the $x$-rays of the forearms, pelvis, knees, and legs below the knee.

\section{Discussion}

Brachydactyly types A1-5, B, C, Edwards and Gale's type, and the types described by Bilginturan et al. (1973), Schott (1978), and Sillence (1978) all involve some degree of shortening or absence of the middle phalanges. None of them involves polydactyly or dermal ridge hypoplasia or ridge dissociation. Each of these types has features distinguishing it from that described here. Brachyphalangy and postaxial polydactyly are seen in chondroectodermal dysplasia (McKusick et al., 1964), but there the distal phalanges are more severely shortened than the middle ones. The normal terminal phalanges and absence of cardiac defect exclude this inherited disorder in the patient reported here.

There have been a number of reports of either extreme narrowing of ridges, or of their dissociation into short segments or dots, or even of total absence of ridges. Dissociated ridges may occur in any dermatoglyphic area of the hands and feet. They are uncommon in normal people but rather frequent in certain medical disorders. In severe dissociations, the ridges are broken into short segments covering the dermatoglyphic area in a disorganised manner so that, frequently, no consistent pattern is recognisable. In mild dissociations, the ridges are broken into short, often dot-like, segments, but the patterns, however, remain clearly definable. Ridge 'disturbances have been observed in phenotypically normal people of different races and ethnic groups. Furuya
(1961) studied ridge dissociation in apparently $\frac{\overrightarrow{0}}{+}$ healthy Japanese. He divided his cases of ridge $\Rightarrow$ : dissociation into two groups depending upon the? extent to which ridged skin was involved: (a) totale dot-and-short ridge patterns; and (b) partial dot-음. and-short ridge patterns. Both types of ridge dissociation showed differences with regard to thee areas in which they occurred, and also to the extentis to which the epidermis was affected. He concluded that the two types of ridge dissociation were deter-: mined by separate autosomal genes, both producing $\vec{\omega}$ dominant inheritance with incomplete penetrance.

A similar pattern of inheritance was described in a single American family with complete congenita absence of ridges in association with transient ${ }^{\circ}$ congenital milia, flexion contractures of digits, and webbing of toes (Baird, 1964). Mild degrees of ridge dissociation were found by Abel (1936) with ao frequency of 1 in 200 among 4000 criminals. There have been several previous reports of non-familialo ridge dissociation in malformations of the extremities? (Abel, 1936; Schade, 1937; Grebe, 1940), but noneo had the specific malformations described in the case presented here. Furthermore, the marked ridgeco hypoplasia with ridge dissociation of the present caseco has not been previously reported as an innater character and could tentatively be defined as a types A6 in Bell's classification.

A sporadic abnormality in a girl, such as thato reported here, could be the result of a fresh mutationo of an autosomal dominant congenital defect, or of $a$ non-genetic developmental error. It is impossible tog distinguish between these alternatives and the case is reported in the hope of stimulating further reports from others that might do so.

We would like to thank Dr S. K. Jain, Consultanto Radiologist, Clayton Hospital, Northgate, WakefieldB for the $x$-rays of our patient.

MARTIN d'A. Crawfurd ANDO P. SALDAÑA-GARCIA The Kennedy-Galton Centre Harperbury Hospital Harper Lane, Shenley, Radlett, Herts WD7 9HQN

\section{References}

Abel, W. (1936). Uber Störungen der Papillarmuster. Ko Gestörte Papillarmuster in Verbindung mit einiger körperlichen und geistigen Anomalien. Zeitschrift fü̈f Morphologie und Anthropologie, 36, 1-38.

Baird, H. W. (1964). Kindred showing congenital absence of the dermal ridges (fingerprints) and associated anomalies $\frac{\vec{D}}{\mathrm{D}}$ Journal of Pediatrics, 64, 621-631.

Bass, H. N. (1968). Familial absence of middle phalanges with nail dysplasia: a new syndrome. Pediatrics, 42, 318-323. 
Bell, J. (1951). On brachydactyly and symphalangism. In Treasury of Human Inheritance, Vol. 5, pp. 1-31. Cambridge University Press, London.

Biemond, A. (1934). Brachydactylie, nystagmus en cerebellaire ataxie als familiair syndroom. Nederlandsch Tijdschrift voor Geneeskunde, 78, 1423-1431.

Bilginturan, N., Zileli, S., Karacadag, S., and Pirnar, T. (1973). Hereditary brachydactyly associated with hypertension. Journal of Medical Genetics, 10, 253-259.

Christian, J. C., Cho, K. S., Franken, E. A., and Thompson, B. H. (1972). Dominant preaxial brachydactyly with hallux varus and thumb abduction. American Journal of Human Genetics, 24, 694-701.

Edwards, J. A., and Gale, R. P. (1970). A kindred with an unusual congenital hand and foot anomaly: a new autosomal dominant trait with two probable homozygotes (Abst.). American Journal of Human Genetics, 22, 18A.

Furuya, Y. (1961). Genetics of patternless finger dermatoglyphs. Japanese Journal of Human Genetics, 6, 102.

Grebe, H. (1940). Untersuchungen über Papillarlinienveränderungen bei Syndaktylie und Polydaktylie. Zeitschrift für Morphologie und Anthropologie, 39, 62-78.

Liebenberg, F. (1973). A pedigree with unusual anomalies of the elbows, wrist and hands in five generations. South African Medical Journal, 47, 745-747.

McKusick, V. A., Egeland, J. A., Eldridge, R., and Krusen, D. E. (1964). Dwarfism in the Amish. I. The Ellis-van Creveld syndrome. Bulletin of the Johns Hopkins Hospital, 115, 306-336.

Schade, H. (1937). Zur endogenen Entstehung von Gliedmassendefekten. Zeitschrift für Morphologie und Anthropologie, 36, 375-381.

Schott, G. D. (1978). Hereditary brachydactyly with nail dysplasia. Journal of Medical Genetics, 15, 119-122.

Sillence, D. O. (1978). Brachydactyly, distal symphalangism, scoliosis, tall stature, and club feet: a new syndrome. Journal of Medical Genetics, 15, 208-211.

Temtamy, S. A. (1966). Genetic Factors in Hand Malformations. Ph.D. Thesis, Johns Hopkins University.

Requests for reprints to Dr M. d'A. Crawfurd, Division of Inherited Metabolic Diseases, Clinical Research Centre, Watford Road, Harrow, Middlesex HA1 3UJ. 